help required? Can it offer any improvement in performance ? Can it do so in a routine clinical environment? To judge from our own studies, the answer to the latter two questions must be a qualified affirmative. The system was far from perfect, but (using identical information) it made significantly fewer errors than the clinical team-and lest this be thought a criticism of the clinicians concerned, no less an authority than Shepherd (1968), in what is probably the definitive textbook on the subject, cites his own diagnostic accuracy in this field as around $70 \%$, rather less than many of the clinicians we studied.

It must, however, be re-emphasized that we have not yet created a system of "computer diagnosis." What we have created is a system which can be used to help the clinician towards his own diagnosis, and which, if implemented, might well significantly improve the quality of the care which the clinician can give to his patient. We are far from unaware of the difficulties in implementation which face us, and it is to these additional problems that we have now turned our attention.

It is a pleasure to thank Professor J. C. Goligher for his encouragement and advice throughout this investigation; and to thank both Professor Goligher and Mr. D. Johnston for permission to study patients admitted under their care. We thank also the clinicians whose experience forms much of the basis of this report, both for taking part in this investigation and for allowing us to use their experience as a basis for comparison. Finally two of us (D. J. L. and J. C. H.) were aided by a grant from the Medical Research Council, which we also acknowledge with gratitude.

\section{References}

Card, W. (1970). Fournal of the Royal College of Physicians of London, 4, 183. Research, vol. 1, p. 339 . New York, Academic Press.

Edwards, W. (1962). I.E.E.E. Transactions on Human Factors in Electronics, 4, 59 .

Edwards, W. (1966). I.E.E.E. Transactions on Human Factors in Electronics, 7,1 .

Horrocks, J. C., McCann, A. P., Staniland, J. R., Leaper, D. J., and de Dombal, F. T. (1972). British Medical fournal, $2,5$.

Kaplan, R. J., and Newman, J. R. (1966). I.E.E.E. Transactions on Human Factors in Electronics, 7, 49.

Lipkin, M. (1964). In The Diagnostic Process, ed. J. A. Jacquez, p. 255, Ann Arbor, Michigan, Malloy.

Lipkin, M., and Hardy, J. D. (1958). Fournal of the American Medical Association, 166, 113 .

Lodick Gorica, 3, 487.

Lusted, L. B., (1968). In Introduction to Medical Decision Making, p. 3. Springfi, Illinois, Thomad.

Springfield, Illinois, Thomas.
Philips, on Human Factors in Electronics, 7, 7 .

Shepherd, W. A. (1968). In Surgery of the Acute Abdomen, p. 32. Edinburgh,

Taylor, T. R. (1970). Fournal of the Royal College of Physicians of London, 4, 188.

\title{
Abnormal Glomerular Filtration Rate, Renal Plasma Flow, and Renal Protein Excretion in Recent and Short-term Diabetics
}

\author{
J. DITZEL， K. JUNKER
}

British Medical fournal, 1972, 2, 13-19

efferens leading to an increase in the filtration pressure. The increase in protein excretion rate may similarly be a consequence of this process or of an increase in the gloSummary

Glomerular filtration rate and renal plasma flow were simultaneously determined in comparable groups of 43 diabetics less than $\mathbf{4 0}$ years of age and with a duration of diabetes less than 10 years and 32 control subjects. The average glomerular filtration rate in the diabetic group was significantly higher than that in the control group $(P<0.01)$. The average renal plasma flow in the diabetic group was found to be significantly lower than that in the control group $(P<0.05)$. The filtration fraction in both male and female diabetics was significantly higher than in the male and female control groups $(P<0.001)$. These changes were found to be present even in recent juvenile diabetics with disease of a duration of less than one year. No correlation was apparent between the average levels of serum growth hormone and glomerular filtration rate.

The urinary protein excretion was determined in 36 diabetic and 38 healthy subjects comparable with regard to glomerular filtration rate. In the diabetic group there was a greater frequency of cases with higher protein excretion rates $(P<0.02)$. The average protein excretion rate was increased even in diabetics with less than one year's duration of the disease.

The results of the changes in renal haemodynamics in subjects with recent and short-term diabetes are compatible with the presence of a constrictive state of the vas merular permeability with augmented molecular sieving of proteins or both.

\section{Introduction}

It has now been well established, both by the classical inulin clearance and by the clearance of isotope-labelled substances $\left({ }^{57} \mathrm{Co}-\right.$ cyanocobalamin and ${ }^{51} \mathrm{Cr}$-edetic acid complex) that the glomerular filtration rate is increased in diabetics early in their disease compared with healthy persons of similar age and sex (Spühler, 1946; Stalder et al., 1960; Ditzel and Schwartz, 1967; Ditzel et al., 1972). The mechanism of this increase is not known, but three major possibilities exist either alone or in combination. It might be related to an increase in renal plasma flow owing to a dilatation of the vas afferens or to a decrease in renal plasma flow owing to a constriction of the vas efferens, leading to a higher filtration pressure in the glomerular capillaries, or it might be caused by an increased permeability of the glomerular apparatus per se and then possibly associated with an increased molecular sieving of proteins.

To elucidate these possibilities the present study relates glomerular filtration rate to other criteria of renal function and to simultaneous metabolic and endocrine changes in short-term diabetics.

\section{Subjects and Methods}

Simultaneous determinations of glomerular filtration rate and renal plasma flow were made in 75 individuals -43 diabetics 
aged under 40 years (23 males, 20 females) and 32 control subjects. The diabetics were admitted consecutively and had suffered from diabetes for less than 10 years. They had no clinical signs of diabetic microangiopathy and had never had symptomatic diseases affecting kidney function. Their plasma creatinine levels and urinary sediment were normal. Thirty-five diabetics were on insulin, usually a small amount of crystalline mixed with isophane insulin. Eight newly diagnosed diabetics had not started insulin treatment when the kidney function tests were first performed. Altogether 27 were juvenile-onset

TABLE I-Glomerular Filtration Rate (G.F.R.), Renal Plasma Flow (R.P.F.), and Filtration Fraction in Diabetic and Control Subjects

\begin{tabular}{|c|c|c|c|c|c|c|c|c|}
\hline Case No & & $\begin{array}{l}\text { Age in } \\
\text { Years }\end{array}$ & $\begin{array}{c}\text { Duration of } \\
\text { Diabetes (years) }\end{array}$ & Insulin Dose (IU) & Body Surface $\left(m^{2}\right)$ & $\begin{array}{c}\text { G.F.R. } \\
\left(\mathrm{ml} / \mathrm{nin} / \mathbf{1} \cdot \mathbf{7 3} \mathrm{m}^{2}\right)\end{array}$ & $\underset{\left(\mathrm{ml} / \mathrm{min} / \mathrm{i} \cdot \mathbf{7} \mathrm{m} \mathrm{m}^{2}\right)}{\text { R.P. }}$ & Filtration Fraction \\
\hline $\begin{array}{l}1 . . \\
2 . . \\
3 . . \\
4 . . \\
6 . . \\
7 . \\
8 . . \\
10 . \\
11 . \\
12 . \\
13 . \\
14 . \\
16 . \\
17 . \\
18 . \\
19 . \\
20 . \\
21 . \\
22 . \\
23 .\end{array}$ & 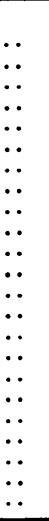 & $\begin{array}{l}15 \\
17 \\
28 \\
22 \\
22 \\
30 \\
20 \\
25 \\
34 \\
33 \\
14 \\
15 \\
31 \\
30 \\
31 \\
24 \\
32 \\
20 \\
39 \\
16 \\
25 \\
39 \\
21 \\
\end{array}$ & $\begin{array}{c}4 \\
1 \\
4 \\
\text { N.D. } \\
1 \\
7 \\
5 \\
2 \\
5 \\
7 \\
7 . D . \\
6 \\
2 \\
2 . D . \\
\text { N.D. } \\
9 \\
1 \\
1 \\
\text { N.D. } \\
6 \\
1 \\
8 \\
1 \\
\end{array}$ & $\begin{array}{l}40 \\
44 \\
32 \\
0 \\
48 \\
40 \\
48 \\
28 \\
40 \\
48 \\
0 \\
68 \\
24 \\
0 \\
20 \\
32 \\
20 \\
12 \\
0 \\
80 \\
44 \\
52 \\
36\end{array}$ & \begin{tabular}{|c|c|} 
Male Diabetics \\
1.66 \\
11.79 \\
1.63 \\
1.83 \\
1.84 \\
1.88 \\
11.79 \\
11.72 \\
1.66 \\
1.75 \\
1.34 \\
1.68 \\
1.63 \\
1.54 \\
1.98 \\
2.09 \\
11.70 \\
1.55 \\
1.73 \\
1.72 \\
1.80 \\
1.86 \\
1.76 \\
\end{tabular} & $\begin{array}{l}157 \\
143 \\
147 \\
138 \\
116 \\
121 \\
156 \\
148 \\
138 \\
133 \\
122 \\
164 \\
151 \\
124 \\
135 \\
140 \\
144 \\
193 \\
158 \\
171 \\
127 \\
132 \\
134 \\
\end{array}$ & $\begin{array}{l}693 \\
806 \\
936 \\
565 \\
577 \\
544 \\
739 \\
847 \\
615 \\
700 \\
499 \\
734 \\
631 \\
563 \\
648 \\
687 \\
678 \\
706 \\
607 \\
672 \\
736 \\
666 \\
680 \\
\end{array}$ & $\begin{array}{l}0.23 \\
0.18 \\
0.16 \\
0.24 \\
0.20 \\
0.22 \\
0.21 \\
0.17 \\
0.22 \\
0.19 \\
0.24 \\
0.22 \\
0.24 \\
0.22 \\
0.21 \\
0.20 \\
0.21 \\
0.27 \\
0.26 \\
0.25 \\
0.17 \\
0.20 \\
0.20 \\
\end{array}$ \\
\hline $\begin{array}{l}\text { Mean } \\
\text { S.D. } \\
\end{array}$ & .. & $\begin{array}{c}25 \cdot 3 \\
\pm 7.58 \\
\end{array}$ & $\begin{array}{r}3 \cdot 1 \\
\pm 2 \cdot 91 \\
\end{array}$ & $\begin{array}{r}33 \\
\pm 21.4 \\
\end{array}$ & $\begin{array}{r}1.74 \\
\pm 0.153 \\
\end{array}$ & $\begin{array}{r}143.1 \\
\pm 18.0 \\
\end{array}$ & $\begin{array}{l}675 \cdot 2 \\
\pm 100 \cdot 4 \\
\end{array}$ & $\begin{array}{r}0.213 \\
\pm 0.029 \\
\end{array}$ \\
\hline $\begin{array}{l}24 . . \\
25 . . \\
26 . \\
27 . \\
28 . \\
29 . \\
30 . \\
31 . \\
32 . \\
34 . \\
35 . \\
36 . \\
37 . \\
38 .\end{array}$ & 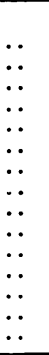 & $\begin{array}{l}39 \\
38 \\
20 \\
28 \\
24 \\
30 \\
36 \\
24 \\
37 \\
38 \\
30 \\
21 \\
24 \\
32 \\
36\end{array}$ & & & \begin{tabular}{|c|} 
Male Controls \\
1.66 \\
1.61 \\
1.73 \\
1.86 \\
1.57 \\
1.80 \\
1.60 \\
1.92 \\
1.70 \\
1.78 \\
1.77 \\
1.89 \\
1.74 \\
1.63 \\
1.90 \\
\end{tabular} & $\begin{array}{l}117 \\
137 \\
124 \\
114 \\
125 \\
106 \\
120 \\
168 \\
146 \\
143 \\
107 \\
157 \\
144 \\
98 \\
125\end{array}$ & $\begin{array}{r}695 \\
993 \\
1105 \\
855 \\
862 \\
709 \\
701 \\
914 \\
730 \\
611 \\
481 \\
803 \\
706 \\
682 \\
742\end{array}$ & $\begin{array}{l}0.17 \\
0.14 \\
0.11 \\
0.13 \\
0.15 \\
0.15 \\
0.17 \\
0.18 \\
0.20 \\
0.23 \\
0.22 \\
0.20 \\
0.20 \\
0.14 \\
0.17\end{array}$ \\
\hline $\begin{array}{l}\text { Mean : } \\
\text { S.D. }\end{array}$ & .. & $\begin{array}{l}30.5 \\
\pm 6.67\end{array}$ & & & $\begin{array}{c}1.74 \\
\pm 0.115\end{array}$ & $\begin{array}{r}128 \cdot 7 \\
\pm 19.9\end{array}$ & $\begin{array}{r}772.6 \\
\pm 155.0\end{array}$ & $\begin{array}{r}0.171 \\
\pm 0.035\end{array}$ \\
\hline $\mathbf{P}$ & .. & & & & & $<0.05$ & $<0.05$ & $<0.001$ \\
\hline $\begin{array}{l}39 . . \\
40 . . \\
41 . \\
43 . \\
44 . \\
45 . \\
46 . \\
48 . . \\
49 . . \\
51 . \\
52 . \\
53 . . \\
54 . \\
55 . . \\
57 . . \\
58 . .\end{array}$ & 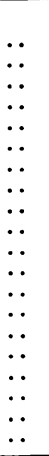 & $\begin{array}{l}24 \\
15 \\
12 \\
11 \\
33 \\
37 \\
15 \\
16 \\
34 \\
36 \\
17 \\
16 \\
31 \\
38 \\
14 \\
24 \\
20 \\
15 \\
17 \\
32\end{array}$ & $\begin{array}{c}6 \\
1 \\
7 \\
1 \\
\text { N.D. } \\
1 \\
4 \\
2 \\
1 \\
8 \\
8 \\
2 \\
2 \\
2 \\
7 \\
6 \\
2 \\
\text { N.D. } \\
8 \\
1\end{array}$ & $\begin{array}{r}48 \\
36 \\
36 \\
32 \\
0 \\
0 \\
56 \\
56 \\
44 \\
32 \\
64 \\
36 \\
0 \\
28 \\
80 \\
36 \\
32 \\
0 \\
44 \\
24\end{array}$ & \begin{tabular}{|c|c|} 
Female Diabetics \\
1.59 \\
1.57 \\
1.24 \\
1.18 \\
1.69 \\
1.58 \\
1.53 \\
1.75 \\
1.65 \\
1.69 \\
1.69 \\
1.66 \\
1.67 \\
1.60 \\
1.68 \\
1.54 \\
1.66 \\
1.36 \\
1.65 \\
1.66
\end{tabular} & $\begin{array}{l}117 \\
119 \\
159 \\
165 \\
101 \\
171 \\
150 \\
169 \\
128 \\
129 \\
133 \\
102 \\
125 \\
125 \\
170 \\
147 \\
112 \\
125 \\
147 \\
147\end{array}$ & $\begin{array}{l}649 \\
673 \\
598 \\
578 \\
552 \\
725 \\
839 \\
724 \\
611 \\
744 \\
593 \\
525 \\
758 \\
667 \\
749 \\
655 \\
561 \\
630 \\
711 \\
547\end{array}$ & $\begin{array}{l}0.18 \\
0.18 \\
0.27 \\
0.29 \\
0.18 \\
0.24 \\
0.18 \\
0.23 \\
0.21 \\
0.17 \\
0.22 \\
0.19 \\
0.16 \\
0.19 \\
0.23 \\
0.22 \\
0.20 \\
0.20 \\
0.21 \\
0.27\end{array}$ \\
\hline $\begin{array}{l}\text { Mean } \\
\text { S.D. }\end{array}$ & . & $\begin{array}{c}22 \cdot 9 \\
\pm 9 \cdot 39\end{array}$ & $\begin{array}{r}3.5 \\
\pm 2.95\end{array}$ & & $\begin{array}{c}1.58 \\
\pm 0.153\end{array}$ & $\begin{array}{r}137 \cdot 1 \\
\pm 22 \cdot 3\end{array}$ & $\begin{array}{r}654.5 \\
\pm 85.3\end{array}$ & $\begin{array}{r}0.211 \\
\pm 0.034\end{array}$ \\
\hline $\begin{array}{l}59 . . \\
60 . . \\
61 . . \\
62 . . \\
63 . . \\
64 . . \\
66 . . \\
67 . . \\
68 . . \\
79 . . \\
71 . . \\
72 . . \\
73 . . \\
75 . .\end{array}$ & 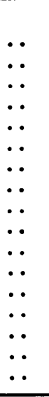 & $\begin{array}{l}23 \\
26 \\
21 \\
25 \\
25 \\
34 \\
36 \\
33 \\
35 \\
25 \\
22 \\
15 \\
17 \\
35 \\
35 \\
22 \\
31\end{array}$ & & & \begin{tabular}{|c|} 
Female Controls \\
1.44 \\
1.67 \\
1.60 \\
1.48 \\
1.84 \\
1.86 \\
1.58 \\
1.60 \\
1.73 \\
1.54 \\
1.36 \\
1.40 \\
1.46 \\
1.48 \\
1.36 \\
1.88 \\
1.52 \\
\end{tabular} & $\begin{array}{l}118 \\
137 \\
129 \\
142 \\
127 \\
95 \\
128 \\
150 \\
119 \\
154 \\
109 \\
123 \\
95 \\
173 \\
95 \\
96 \\
102\end{array}$ & $\begin{array}{r}888 \\
1168 \\
1005 \\
753 \\
784 \\
491 \\
638 \\
639 \\
568 \\
698 \\
731 \\
636 \\
492 \\
947 \\
452 \\
709 \\
575\end{array}$ & $\begin{array}{l}0.13 \\
0.12 \\
0.13 \\
0.19 \\
0.16 \\
0.19 \\
0.20 \\
0.23 \\
0.21 \\
0.22 \\
0.15 \\
0.19 \\
0.19 \\
0.18 \\
0.21 \\
0.14 \\
0.18\end{array}$ \\
\hline $\begin{array}{l}\text { Mean } \\
\text { S.D. }\end{array}$ & $\ddot{x}$ & $\begin{array}{c}27 \cdot 1 \\
\pm 6 \cdot 77 \\
\end{array}$ & & & $\begin{array}{c}1.58 \\
\pm 0.169 \\
\end{array}$ & $\begin{array}{r}123.1 \\
\pm 23.2 \\
\end{array}$ & $\begin{array}{r}716 \cdot 1 \\
\pm 194 \cdot 9 \\
\end{array}$ & $\begin{array}{r}0.177 \\
\pm 0.033 \\
\end{array}$ \\
\hline $\mathbf{P}$ & .. & & & & & $0.05<P<0.1$ & N.S. & $<0.001$ \\
\hline
\end{tabular}

N.D. $=$ Newly discovered. 
and 16 adult-onset diabetics classified according to the W.H.O. Expert Committee on Diabetes Mellitus, 1966. Fasting blood sugar levels were determined in all diabetics before the clearance determinations and the values varied from 40 to $340 \mathrm{mg} / 100 \mathrm{ml}$. In addition, the blood sugar level was determined in the morning and late afternoon, and the 24-hour urinary glucose excretion on the same day was also recorded. None of the patients suffered from symptomatic hypoglycaemia during the examination. They were all under fairly good metabolic control and none had ketoacidosis.

The 32 control subjects ( 15 males, 17 females) were referred to the hospital for examination and no organic disease was found. They were selected according to age and sex to match the diabetic group. Data on all subjects are given in Table I with regard to sex, age, and body surface area and on the diabetic subjects concerning duration of diabetes and insulin dose. The average age of the diabetics was only slightly lower than that of the controls, but it is important to note that the body surface areas were identical in both groups.

\section{GLOMERULAR FILTRATION RATE}

Glomerular filtration rate was determined either by the classical continuous infusion technique with inulin or by the intravenous single-injection technique with ${ }^{51} \mathrm{Cr}$-edetic acid (Aurell and Ditzel, 1970). All clearance tests were performed in the morning with the subjects in the supine position. The diabetic patients received their usual insulin dose at 7 a.m. before the clearance study. After a priming dose of inulin a sustaining infusion of inulin was given by means of a constant infusion pump. After an equilibration period of not less than 30 minutes three clearance tests were carried out in each patient. Blood was drawn through an indwelling antecubital venous catheter in the middle of each test. Catheterization of the bladder was not performed, and for that reason the length of the clearance tests was about 30 minutes.

Inulin clearance (Laevosan) was analysed according to the method of Higashi and Peters (1950) with the modification of Froesch et al. (1957). The ${ }^{51} \mathrm{Cr}$-edetic acid clearance was determined by studying the plasma disappearance curve after a single intravenous injection of approximately $100 \mu \mathrm{Ci}$ of ${ }^{51} \mathrm{Cr}$-edetic acid for at least four hours while taking venous blood samples every five minutes for the first 30 minutes and thereafter every 30 minutes (Aurell and Ditzel, 1970). ${ }^{51} \mathrm{Cr}$-edetic acid was supplied from the Radiochemical Centre, Amersham, England, and the samples were counted in an automatic welltype scintillation counter (Selectronic, Denmark). From the plasma disappearance curve the clearance value was calculated according to the method of Sapirstein et al. (1955). Previous comparison in this laboratory of the renal clearance of inulin and ${ }^{51} \mathrm{Cr}$-edetic acid has shown good agreement. The regression line between the ${ }^{51} \mathrm{Cr}$-edetic acid and inulin clearances is ${ }^{51} \mathrm{Cr}$-edetic acid $=0.84 \times$ inulin $+12.27(\mathrm{r}=0.97, \mathrm{P}<0.001)$ (Aurell and Ditzel, 1970). For comparison the ${ }^{51} \mathrm{Cr}$-edetic acid clearance values in this study were corrected according to this equation and to the standard body surface area of $1.73 \mathrm{~m}^{2}$.

\section{RENAL PLASMA FLOW}

Renal plasma flow was determined either by the aminohippurate (PAH) clearance method of Smith et al. (1945) modified by Sims (1961) or by the ${ }^{125} \mathrm{I}$-Hippuran clearance as indicated by Ram et al. (1967). Comparison in this laboratory of these two methods in 20 patients with normal and impaired renal function showed good correlation, the regression line being PAH $=1.132 \times{ }^{125}$ I-Hippuran $+14.24(\mathrm{r}=0.099, \mathrm{P}<0.001)$. For comparison the ${ }^{125} \mathrm{I}$-Hippuran clearance values were corrected according to this equation and to the standard body surface area of $1.73 \mathrm{~m}^{2}$.

\section{SERUM GROWTH HORMONE}

In a second group of 12 diabetics ( 5 males, 7 females) aged under 40 years who had had diabetes for less than 10 years and had no clinical evidence of diabetic microangiopathy, serum growth hormone was determined according to the method of Orskov et al. (1968) before and four times during the estimation of ${ }^{51} \mathrm{Cr}$-edetic acid clearance. The sex, age, and duration of diabetes in this group are shown in Table II.

\section{PROTEIN EXCRETION}

In a third group of 74 individuals -36 diabetics (13 males, 23 females) and 38 healthy subjects (9 males, 29 females)-the renal protein excretion was determined. All subjects were less than 50 years of age and had never had symptomatic kidney disease or hypertension. They satisfied the following criteria: absence of clinical proteinuria by Albustix, endogenous creatinine clearance higher than $70 \mathrm{ml} / \mathrm{min} / 1.73 \mathrm{~m}^{2}$, normal concentrating ability, and normal urinary sediment. Of the diabetic cases 27 were of the juvenile-onset type and only nine were of the adult-onset type. Ten patients had had diabetes for less than one year. The average duration of diabetes was $7 \cdot 1$ years. Pertinent data with respect to sex, average age, duration of diabetes, and creatinine clearance values are given in Table III. Analysis showed that the

TABLE II-Serum Growth Hormone Levels before (0 min) and during the Determination of Glomerular Filtration Rate in 12 Short-term Diabetics

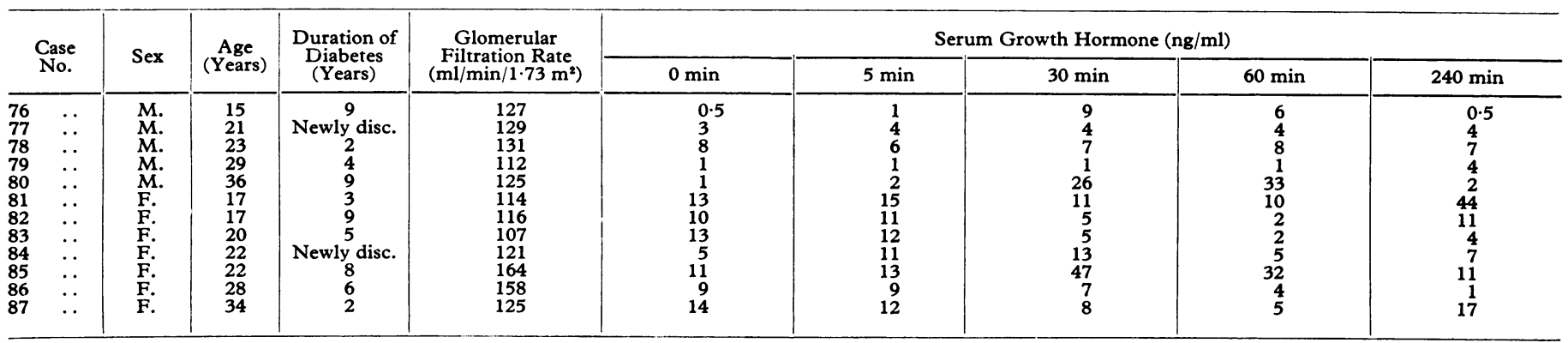

TABLE III-Average Urinary Protein Excretion and Protein Concentration in the Glomerular Filtrate in Normal and Diabetic Subjects

\begin{tabular}{|c|c|c|c|c|c|c|c|c|}
\hline \multicolumn{3}{|c|}{ Study Group } & \multirow{2}{*}{$\begin{array}{l}\text { No. of Cases } \\
\text { M. } 9 \\
\text { F. } 29 \\
\text { M. } 13 \\
\text { F. } 23\end{array}$} & \multirow{2}{*}{$\begin{array}{l}\text { Age (years) } \\
35 \pm 8 \cdot 4 \\
30 \pm 10 \cdot 2 \\
30 \pm 11 \cdot 1 \\
26 \pm 9 \cdot 3\end{array}$} & \multirow{2}{*}{$\begin{array}{c}\begin{array}{c}\text { Duration } \\
\text { of Diabetes } \\
\text { (years) }\end{array} \\
\\
\begin{array}{l}8 \cdot 4 \pm 7 \cdot 7 \\
6 \cdot 4 \pm 5 \cdot 8\end{array}\end{array}$} & \multirow{2}{*}{$\begin{array}{c}\begin{array}{c}\text { Creatinine } \\
\text { Clearance } \\
\left(\mathrm{ml} / \mathrm{min} / 1 \cdot 73 \mathrm{~m}^{2}\right)\end{array} \\
104 \pm 21 \cdot 0 \\
111 \pm 15 \cdot 1 \\
118 \pm 25 \cdot 3 \\
108 \pm 23 \cdot 4\end{array}$} & \multirow{2}{*}{$\begin{array}{c}\begin{array}{c}\text { Average Urinary } \\
\text { Protein Excretion } \\
\left(\mathrm{mg} / 24 \mathrm{hr} / 1 \cdot 73 \mathrm{~m}^{2}\right)\end{array} \\
80.9 \pm 37.57 \\
82.4 \pm \pm 0.14 \\
148.4 \pm 95.18 \\
117.6 \pm 7.98\end{array}$} & \multirow{2}{*}{ 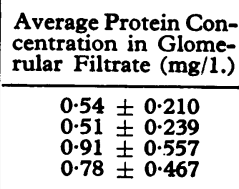 } \\
\hline $\begin{array}{l}\text { Normal . } \\
\text { Diabetic . }\end{array}$ & $\begin{array}{l}\cdots \\
\cdots\end{array}$ & $\begin{array}{l}\cdots \\
\cdots\end{array}$ & & & & & & \\
\hline
\end{tabular}


groups were comparable with respect to average age and creatinine clearance values.

The urinary protein excretion ( $\mathrm{mg} / 24$ hours) was determined after the high molecular components of urine had been separated by gel filtration on Sephadex G-50 as suggested by Jørgensen (1967) using the colorimetric method for low concentrations of protein described by Lowry et al. (1951). Simultaneously the creatinine clearance was determined and both values were corrected to $1.73 \mathrm{~m}^{2}$ of body surface area. On the assumption that tubular reabsorption of protein is slight an estimate of the protein concentration in the glomerular filtrate was calculated by the formula

\section{Protein concentration in urine ( $\mathrm{mg} / 1$.) Creatinine urine : plasma ratio}

The statistical calculation was performed on a desk computer by using the $t$ test, $\chi^{2}$ test, and correlation analysis, all with a level of significance of $P<0.05$.

\section{Results}

The individual and the average values for glomerular filtration rate, renal plasma flow, and filtration fraction in the 75 subjects are set out in Table I.

\section{GLOMERULAR FILTRATION RATE}

The average glomerular filtration rate in the male diabetics was significantly higher $\left(143.1 \pm 18.0 \mathrm{ml} / \mathrm{min} / 1.73 \mathrm{~m}^{2}\right)$ than in the male controls $\left(128.7 \pm 19.9 \mathrm{ml} / \mathrm{min} / 1.73 \mathrm{~m}^{2}\right)(P<0.05)$. Similarly the rate in the female diabetics was higher than in the female non-diabetic subjects. When the male and female subjects were considered together the average glomerular filtration rate in the diabetic group was $140.3 \pm 20.1 \mathrm{ml} / \mathrm{min} /$ $1.73 \mathrm{~m}^{2}$, which was significantly higher than that in the control group $\left(125.7 \pm 21.6 \mathrm{ml} / \mathrm{min} / 1.72 \mathrm{~m}^{2}\right)(P<0.01)$. The average glomerular filtration rate in 18 recent-onset diabetics was $138.3 \pm 22.3 \mathrm{ml} / \mathrm{min} / 1.73 \mathrm{~m}^{2}$, a figure not significantly different from the average value of $141.7 \pm 18.7 \mathrm{ml} / \mathrm{min} / 1.73 \mathrm{~m}^{2}$ in diabetics with more than one year's duration of the disease. The average glomerular filtration rate in the 27 juvenile diabetics was $143.1 \pm 21.9 \mathrm{ml} / \mathrm{min} / 1.73 \mathrm{~m}^{2}$, a figure not significantly different from that of $135.5 \pm 16.2 \mathrm{ml} / \mathrm{min} / 1.73 \mathrm{~m}^{2}$ in the 16 adult-onset diabetics.

No correlation could be found between the glomerular filtration rate and the duration of diabetes when this was less than 10 years. Neither could any correlation be found between glomerular filtration rate and insulin dose, glucosuria, or the average blood sugar level during the clearance test.

Growth hormone levels during the determination of glomerular filtration rate in 12 short-term diabetics are shown in Table II. The levels fluctuated quite markedly in some of the cases. High levels were observed in cases with a normal glomerular filtration rate (Case 80 ) and low levels could be present in cases with a high glomerular filtration rate. No correlation was apparent between the average levels of growth hormone during the clearance determination and glomerular filtration rate.

\section{RENAL PLASMA FLOW}

The simultaneously determined renal plasma flow in the male diabetics was significantly lower $(675.2 \pm 100.4 \mathrm{ml} / \mathrm{min} /$ $\left.1.73 \mathrm{~m}^{2}\right)$ than in the male controls $(772.6 \pm 155.0 \mathrm{ml} / \mathrm{min} /$ $\left.1.73 \mathrm{~m}^{2}\right)(P<0.05)$. Similarly the average renal plasma flow in the female diabetics was lower than in the female control group. When the male and female subjects were considered together the average renal plasma flow in the diabetic group was $665.5 \pm 93.1 \mathrm{ml} / \mathrm{min} / 1.73 \mathrm{~m}^{2}$, which was significantly lower than the figure for the control group $(742.6 \pm 176.9 \mathrm{ml} / \mathrm{min} /$ $\left.1.73 \mathrm{~m}^{2}\right)(\mathrm{P}<0.05)$. The average renal plasma flow was $632.3 \pm$ $80.1 \mathrm{ml} / \mathrm{min} / 1.73 \mathrm{~m}^{2}$ in recent-onset diabetics, and this was significantly smaller than that of $689.5 \pm 95.9 \mathrm{ml} / \mathrm{min} / 1.73 \mathrm{~m}^{2}$ in subjects with diabetes for more than one year $(P<0.05)$.

No correlation could be found between renal plasma flow and the glomerular filtration rate in either normal persons or diabetics, and no correlation was found between renal plasma flow and insulin dose, glucosuria, or the average blood sugar level.

\section{FILTRATION FRACTION}

The filtration fraction in both male and female diabetics $(0.21 \pm 0.03)$ was significantly higher than in the male $(0.17 \pm$ $0.03)$ and female $(0.18 \pm 0.03)$ control groups $(P<0.001)$. The average filtration fraction in the 18 recent-onset diabetics was $0.22 \pm 0.04$, and this figure was not significantly different from the average value of $0.21 \pm 0.03$ in diabetics of more than one year's standing. No correlation was found between filtration fraction and insulin dose, glucosuria, or blood sugar level.

\section{PROTEIN EXCRETION}

The average values of the 24-hour urinary protein excretion and protein concentration in the glomerular filtrate are given in Table III. Since neither the protein excretion nor the protein concentration differed significantly between the sexes the results have been combined in the subsequent analysis. The protein excretion showed considerable variation in both normals $\left(22-183 \mathrm{mg} / 24 \mathrm{hr} / 1 \cdot 73 \mathrm{~m}^{2}\right)$ and diabetics $(41-364 \mathrm{mg} / 24 \mathrm{hr} /$ $\left.1.73 \mathrm{~m}^{2}\right)$. The average protein excretion rates were 81 and 129 $\mathrm{mg} / 24 \mathrm{hr} / 1.73 \mathrm{~m}^{2}$ in the normal and diabetic groups respectively. Since the urinary protein excretion in the diabetics did not show a normal distribution curve ranking tests were performed. When the individual measurements were distributed into three ranges $-0-100,101-200$, and more than $200 \mathrm{mg} / 24 \mathrm{hr} / 1.73 \mathrm{~m}^{2}-$ and the distributions were compared (Table IV) they were found to differ significantly $(P<0.02)$. In the $\chi^{2}$ calculation it was particularly the diabetic group showing high protein excretion that contributed to the significance; $52 \%$ of the diabetics had protein excretion values greater than $101 \mathrm{mg} / 24 \mathrm{hr}$ compared with $26 \%$ in the normal group. The average urinary protein excretion was $142 \mathrm{mg} / 24 \mathrm{hr}$ in recent-onset diabetics and $123 \mathrm{mg} / 24 \mathrm{hr}$ in patients with diabetes of more than one year's duration. These figures are not significantly different, nor could any difference be found in urinary protein excretion between juvenile-onset and adult-onset diabetics.

TABLE IV-Frequency Distributions of Urinary Protein Excretion and Protein Concentration in the Glomerular Filtrate in Normal and Diabetic Subjects

\begin{tabular}{|c|c|c|c|c|c|c|c|c|c|}
\hline \multirow{2}{*}{\multicolumn{3}{|c|}{ Study Group }} & \multirow{2}{*}{$\begin{array}{l}\text { No. of } \\
\text { Subjects }\end{array}$} & \multirow{2}{*}{ 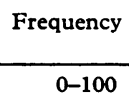 } & $\begin{array}{l}\text { Distribution of Urinary } \\
\left(\mathrm{mg} / 24 \mathrm{hr} / 1.73 \mathrm{~m}^{2}\right)\end{array}$ & \multirow{2}{*}{$\frac{\text { Protein Excretion }}{>200}$} & \multicolumn{3}{|c|}{$\begin{array}{l}\text { Frequency Distribution of Protein Concentration in Glome- } \\
\text { rular Filtrate (mg/1.) }\end{array}$} \\
\hline & & & & & $101-200$ & & $0-0.50$ & $0.51-1.00$ & $>1.00$ \\
\hline $\begin{array}{l}\text { Normal } \\
\text { Diabetic }\end{array}$ & $\because$. & $\begin{array}{l}\cdots \\
\cdots\end{array}$ & $\begin{array}{l}38 \\
36\end{array}$ & $\begin{array}{l}28 \\
17\end{array}$ & $\begin{array}{l}10 \\
14\end{array}$ & $\begin{array}{l}0 \\
5\end{array}$ & $\begin{array}{l}21 \\
14\end{array}$ & $\begin{array}{l}16 \\
13\end{array}$ & $\begin{array}{l}1 \\
9\end{array}$ \\
\hline Total & . & . & 74 & 45 & 24 & 5 & 35 & 29 & 10 \\
\hline \multicolumn{3}{|c|}{ Significance } & .. & \multicolumn{3}{|c|}{$P<0.02$} & \multicolumn{3}{|c|}{$P<0.02$} \\
\hline
\end{tabular}


From the urinary protein concentration and the ratio of the creatinine concentration in urine and plasma an estimate was made of the protein concentration in the glomerular filtrate. The protein concentration in the glomerular filtrate of the healthy subjects varied from 0.12 to $1.25 \mathrm{mg} / 1$., with an average of $0.52 \mathrm{mg} / 1$. In the diabetics the protein concentration in the glomerular filtrate varied from 0.30 to $2.26 \mathrm{mg} / 1$., with an average of $0.83 \mathrm{mg} / 1$. Since the values for the diabetics did not show a normal distribution curve the frequency distribution was used for the statistical analysis. The frequency distribution with respect to increasing concentration of protein in the glomerular filtrate is shown in Table IV. A $\chi^{2}$ test showed that the distribution in the diabetics differed significantly from that of the normal subjects $(P<0.02)$. Among the diabetics there was a greater incidence of patients with high protein concentration in the glomerular filtrate than in normal persons. No difference in the protein concentration of the glomerular filtrate could be shown between recent-onset diabetics and diabetics of more than one year's standing or between juvenileonset and adult-onset diabetics. No correlation could be shown between either the protein excretion rate or the protein concentration in the glomerular filtrate and the creatinine clearance or insulin dose.

\section{Discussion}

The dominant role of diabetic nephropathy as a cause of death in late diabetes stresses the importance of studying the changes in renal structure and renal function early in the disease. Recent studies with the electron microscope in short-term diabetes have clearly shown the presence of measurable thickening of the basement membrane and mesangial region long before the advent of any clinical evidence of nephropathy (Lazarow, 1964, $\varnothing$ sterby-Hansen, 1965, 1971). Our study sought a better understanding of the functional disorders of the glomerular capillaries and renal haemodynamics of early diabetes.

In both young and old diabetics with no signs of diabetic
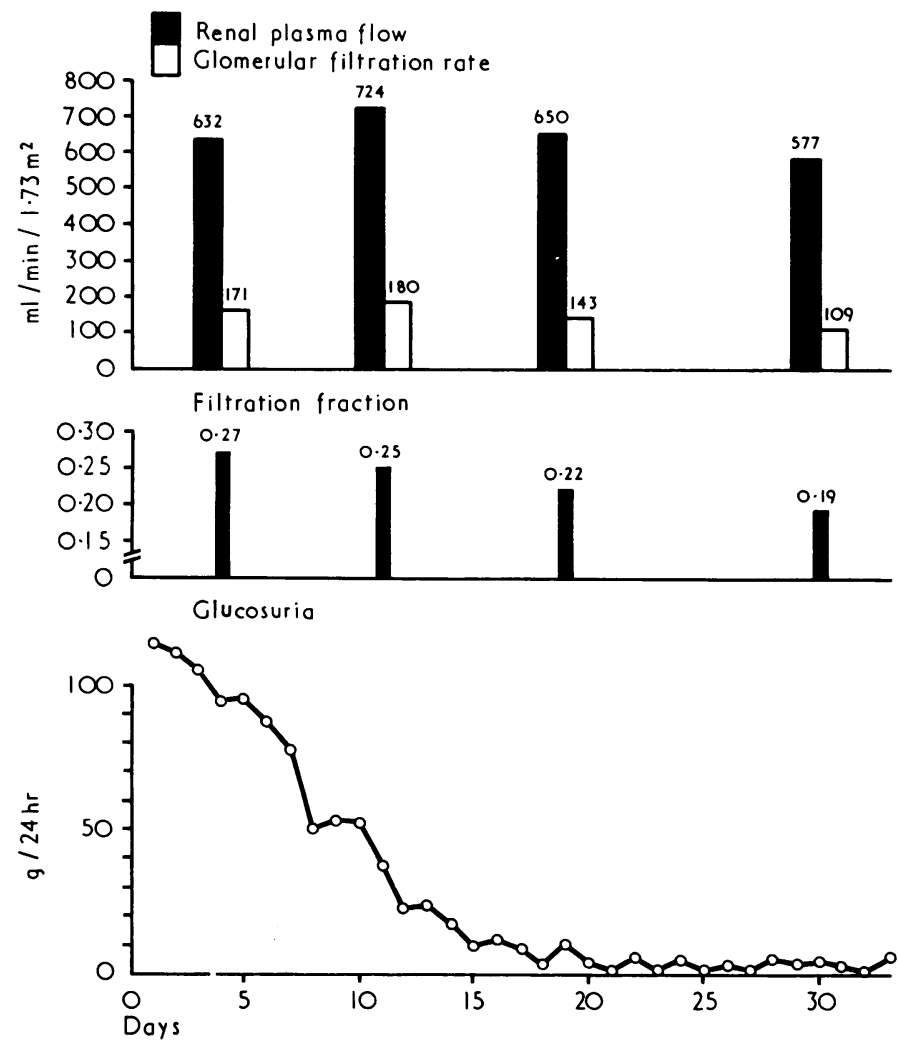

Renal plasma flow, glomerular filtration rate, and filtration fraction in relation to control of metabolism in a juvenile female diabetic patient microangiopathy the glomerular filtration rate is increased (Spühler, 1946; Stalder et al., 1960; Ditzel and Schwartz, 1967; Ditzel et al., 1972); this was confirmed in our patients on whom renal function tests were performed. The increase was not correlated to the duration of the disease within the first 10 years, and the average glomerular filtration rate did not differ in patients with recent diabetes (up to one year's duration) and in those with disease of longer duration. It is well known that the glomerular filtration rate decreases late in the disease as clinical signs of diabetic nephropathy set in and progress (Robertson et al., 1951; Brun et al., 1953; Latotzki, 1958).

The increase in glomerular filtration rate was found to be linked with a significant reduction in the average renal plasma flow; the filtration fraction was, therefore, greatly increased. This pattern of kidney function tests is compatible with constriction of the vas efferens, leading to an increase in the filtration pressure. A similar pattern of renal function was found in a small series of diabetics by Amsler (1952) and in a larger number of adult diabetics by Tojo et al. (1965). Stalder et al. (1960), in a study of 18 children with diabetes of short duration, found strikingly high values of both glomerular filtration rate and filtration fraction in most of the patients. They found that the high glomerular filtration rate appeared to return to normal with control of the disease. Serial determination of renal function tests in our patients also showed the return to normal values of glomerular filtration rate and filtration fraction with good control of their metabolic state. Such a case is illustrated in the Chart. The reversibility in renal haemodynamics indicates that in particular the constriction of the vas efferens leading to glomerular congestion is a functional and reversible change. In diabetics in whom the glomerular filtration rate remains high despite good control over a prolonged period there may be a more irreversible change in the calibre of the vas efferens. Arteriolosclerosis in both the vasa efferentia and afferentia is a characteristic feature in diabetes (Thomsen, 1965).

The aetiology of these changes in renal haemodynamics in early diabetes is not clear, but hormonal, metabolic, and central nervous factors may be implicated. Recently the level of serum growth hormone has been suggested as an important factor in the development of diabetic vascular disease (Lundbaek et al., 1970). Since this hormone has been shown to increase the glomerular filtration rate in normal persons (Corvilain and Abramow, 1962) and hypophysectomized diabetics (Teuscher and Zahnd, 1970) it was estimated in diabetics with high and normal glomerular filtration rates. No relation could be found between the level of growth hormone and the glomerular filtration rate in these cases. Further, growth hormone tends to increase renal plasma flow in normal subjects, and in the present series of diabetics the renal plasma flow was significantly decreased.

Adrenaline in small doses reduces the PAH clearance and increases the filtration fraction, and according to Smith et al. (1940) this may be explained on the basis of efferent arteriolar constriction. It is generally accepted that hypoglycaemia or a pronounced fall in blood sugar after insulin administration mobilizes catecholamines. During hypoglycaemia in four diabetics with normal kidney function Latotzki (1964) showed that the inulin clearance increased and the PAH clearance decreased, with a pronounced increase in the filtration fraction. In our laboratory we have found similar variations in the clearance tests of young recent-onset diabetics with pronounced hyperglycaemia in whom a fall in blood sugar was produced not reaching hypoglycaemic levels. It is of interest that Christensen (1970) found high levels of blood catecholamines in untreated diabetics during ketoacidosis and high blood sugar and that the concentration of catecholamines decreased as the metabolism was regulated. Future studies of the relation between the actual levels of plasma catecholamines and renal function tests in diabetes would therefore be of great interest.

Tissue hypoxia may also be implicated in the production of the renal functional changes of diabetes. Pauli et al. (1968) studied renal function during prolonged exposure to carbon 
monoxide in man, in which the oxyhaemoglobin dissociation curve is shifted to the left, leading to an impairment in the oxygen delivery to the tissues. The striking change of renal function in the 36 hours after starting inhalation of carbon monoxide was a considerable increase of glomerular filtration rate, while the average renal plasma flow was little changed. These changes could be explained by a selective constriction of the vas efferens balanced by a dilatation of the afferent arteriole, leading to an increased filtration pressure. Prolonged hypoxia has long been suggested in diabetes (Ashton, 1951; Ditzel and Rooth, 1955). We recently showed that the oxyhaemoglobin dissociation curves of many ambulatory diabetics are shifted to the left (Ditzel, 1972). This shift is due to metabolic changes in the erythrocytes, probably geared to an increase in the activity of the polyol pathway of glucose metabolism. Thus hypoxia may be the factor producing the observed renal functional changes.

Reports on the effect of glucose loading on the glomerular filtration rate are conflicting, mainly because many investigators have ignored the simultaneous increase in plasma volume produced by the infusions which in itself increases both glomerular filtration rate and renal plasma flow (Latotzki, 1964). In our study no relation could be found between the renal function tests and the level of blood sugar during the test periods.

Although many of the diabetics in our study might have shown ultrastructural thickening of the basement membrane of the glomerular capillaries if kidney biospies had been performed the glomerular filtration rate was nevertheless increased. It seems, therefore, that thickening of the basement membrane does not impede a normal or even high glomerular filtration rate. This is also true in other kidney disorders. Thus abnormally high glomerular filtration rates may be observed in cases of the nephrotic syndrome early during the disease (Emerson and Dole, 1943; Spühler, 1946; Bruck et al., 1954). This rise in the glomerular filtration rate has been explained as due to increased permeability of the basement membrane or increased renal blood flow or both.

Proteinuria was not found in the present study when ordinary clinical tests were used. However, these tests are inadequate for a study of protein excretion by normal kidneys. The existence of a slight physiological proteinuria is well known and the results of several investigations indicate that it mostly originates from a process of glomerular filtration followed by tubular reabsorption (Lambert et al., 1970). Bing (1936) and Jorgensen (1967), however, produced evidence that the tubular reabsorption of protein is slight in cases of normal and pathological proteinuria in man. If this assumption is correct the protein concentration in the glomerular filtrate may be estimated from its concentration in the urine and the ratio of the creatinine concentration in urine and plasma. In the present study the diabetic and control groups had strictly comparable creatinine clearances. Despite this there was a significant increase in both the protein excretion rate and the protein concentration in the glomerular filtrate among the diabetics. The normal urinary protein excretion rate was found to vary from 22 to $183 \mathrm{mg} / 24 \mathrm{hr}$, and this excretion agrees well with the figures given in the literature (Berggaard, 1970). In the diabetics a larger number had higher excretion rates and higher concentrations of protein in the glomerular filtrate, and this increase was already apparent in cases of diabetes of recent onset.

Panzram et al. (1967) studied the urinary protein excretion in a heterogeneous group of 130 diabetics with and without diabetic microangiopathy and found a significant increase in protein excretion compared with that of 140 control subjects. They showed a continuous increase in the average protein excretion with the duration of diabetes. The concentration of normal physiological proteinuria in their series was, however, significantly lower than in the present and other studies (Berggaard, 1970). Using disc electrophoresis Hemmingsen et al. (1970) studied the pattern of protein in the urine of 73 diabetics. In this study the values given for physiological proteinuria were much higher than those normally given, but the observations indicated an increased urinary protein excretion among the diabetics from the onset of the disease. The protein pattern differed somewhat in recent juvenile diabetics from that of cases of longer duration. The former excreted relatively less albumin and more gammaglobulin. Keen and Chlouverakis (1964) studied the urinary excretion of albumin using a sensitive immunoassay method in groups of early diabetics, "borderline" diabetics, and normal subjects of all ages. Diabetics were found to excrete the most and normal subjects the least amount of albumin of the three groups.

The mechanism leading to the increase in urinary protein excretion is not known. It has been suggested that it might be due to increased permeability of the glomerular basement membrane as a consequence of the electron-microscopic pathological changes seen early in the clinical course of the condition (Panzram et al., 1967; Hemmingsen et al., 1970). However, $\varnothing$ sterby-Hansen (1971) has shown by quantitative electronmicroscopical studies that the glomerular basement membrane is morphologically normal at the onset of diabetes and that thickening of the basement membrane can first be shown after three to five years of diabetes. In the present study even the recent-onset diabetics showed increased urinary excretion of protein, and this finding would not agree with the electronmicroscopical observations of $\varnothing$ sterby-Hansen, as suggested by Panzram et al. (1967) and Hemmingsen et al. (1970). Other possibilities, therefore, have to be considered.

Unfortunately no simultaneous measurement was made of the renal haemodynamics in the diabetics in whom urinary protein excretion was studied, but when the result of the first part of this report showing abnormal glomerular filtration rate, renal plasma flow, and filtration fraction in a comparable group of recent diabetics is studied it is tempting to suggest that the increase in urinary protein excretion, like the increased filtration fraction, may be a consequence of glomerular congestion and mechanical distension of the capillary wall produced by prolonged functional constriction of the efferent arterioles. In cases of longer duration of diabetes morphological changes in the basement membrane may in addition give rise to an augmented glomerular permeability by an increase in pore radius or changes in the slit membranes. At the present time, however, our knowledge of the level of the glomerular structures at which the sieving process takes place is so limited that this question remains unanswered.

The present results show the existence of a subclinical functional microangiopathy in the kidneys (Ditzel, 1968), and it is possible that the abnormal kidney haemodynamics and protein excretion from the onset of diabetes may be participating in the mechanism leading to the development of diabetic nephropathy.

This study was supported by the Novo Fund, Copenhagen, Denmark.

\section{References}

Amsler, H. A. (1952). Diabetes mellitus und Kapillarpermeabilität. Die Permabilität der Glomeruluskpillaren. Zürich, Juris.

Ashton, N. (1951). British fournal of Ophthalmology, 35, 189.

Aurell, M., and Ditzel, J. (1970). In 7th International Congress on Clinical Chemistry, GenevalEvian, 1969, vol. 3, p. 405. Basel, Karger.

Berggaard, I. (1970). In Proteins in Normal and Pathological Urine, p. 7. Basel, Karger.

Bing, J. (1936). Studies on Proteinuria, p. 38. Copenhagen, Munksgaard.

Bruck, E., Rapoport, M., and Rubin, M. I. (1954). Fournal of Clinical Investigation, 33, 699.

Brun, C., Gormsen, H., Hilden, T., Iversen, P., and Raaschou, F. (1953) American fournal of Medicine, $15,187$.

Christensen, N. J. (1970). Diabetologia, 6, 623.

Corvilain, J., and Abramow, M. (1962). Fournal of Clinical Investigation, 41,1230 .

Ditzel, J. (1968). Diabetes, 17, 388.

Ditzel, J. (1972). Lancet. In press.

Ditzel, J., Brinklov, M., and Vestergaard, P. (1972). Hormone and Metabolic Research. 4, 8.

Ditzel, J., and Rooth, G. (1955). Diabetes, 4, 474. 
Ditzel, J., and Schwartz, M. (1967). Diabetes, 16, 264.

Emerson, K., jun., and Dole, V. P. (1943). Fournal of Clinical Investigation, 22, 447.

Froesch, E. R., Reardon, J. B., and Renold, A. E. (1957). fournal of Laboratory and Clinical Medicine, 50, 918.

Hemmingsen, L., Hoiby, N., and Kragh-Søtensen, P. (1970). Diabetologia, 6, 512

Higashi, A., and Peters, L. (1950). Fournal of Laboratory and Clinical Medicine, 35, 475

Jorgensen, M. B. (1967). Acta Medica Scandinavica, 181, 153.

Keen, H., and Chlouverakis, C. (1964). Lancet, 2, 1155.

Lambert, P. P., Gassee, J. P., and Askenasi, R. (1970). In Proteins in Normal and Pathological Úrine, p. 67. Basel, Karger.

Latotzki, H. (1958). Zeitschrift für klinische Medizin, 155, 158.

Latotzki, H. (1964). In Diabetische Angiopathie, p. 81. Berlin, Akademie.

Lazarow, A. (1964). In Small Blood Vessels Involvement in Diabetes Mellitus, p. 9. Washington, D.C., American Institute of Biological Science.

Lowry, O. H., Rosebrough, N. J., Farr, A. L., and Randall, R. J. (1951). fournal of Biological Chemistry, 193, 265.

Lundbaek, K., et al. (1970). Lancet, $2,121$.

Ørskov, H., Thomsen, H. G., and Yde, H. (1968). Nature, 219, 193.

Orsterby-Hansen, R. (1965). Diabetologia, 1, 97.

Osterby-Hansen, R. (1971). In Microcirculatory Approaches to Curren Therapeutic Problems, p. 142. Basel, Karger.
Panzram, G., Anger, G., and Wöllner, H. (1967). Deutsche medizinische Wochenschrift, 92, 1013.

Pauli, H. G., Truniger, B., Larsen, J. K., and Mulhausen, R. O. (1968) Scandinavian fournal of Clinical and Laboratory Investigation, 22 Suppl. No. 103, p. 55

Ram, M. D., Evans, K., and Chisholm, G. D. (1967). Lancet, 2, 645.

Robertson, J. A., Grey, C. H., and Baynes, A. H. (1951). Archives of Internal Medicine, 87, 570

Sapirstein, L. A., Vidt, D. G., Mandel, M. J., and Hanusek, G. (1955) American fournal of Physiology, 181, 330.

Sims, E. A. H. (1961). Diabetes, 10, 190.

Smith, H. W., Chasis, H., Goldring, W., and Ranges, H. A. (1940). Fournal of Clinical Investigation, 19, 751 .

Smith, H. W., Finckelstein, N., Aliminosa, L., Crawford, B., and Braber, $M$. (1945). Fournal of Clinical Investigation, 24, 388.

Spühler, O. (1946). In Zur Physio-Pathologie der Niere, p. 45. Bern, Hans Huber.

Stalder, G. R., Schmid, R., and Wolff, M. V. (1960). Deutsche medizinische Wochenschrift, 85, 346 .

Teuscher, A., and Zahnd, G. (1970). Excerpta Medica. International Congress Series, 209, 141 .

Thomsen, A. C. (1965). The Kidney in Diabetes Mellitus, p. 72. Copenhagen, Munksgaard.

Tojo, S., Tsuchiya, T., and Yokota, S. (1965). Tonyobyo, 8, 239.

\title{
Sucrose Malabsorption in Greenland
}

\author{
A. MCNAIR， E. GUDMAND-HØYER， S. JARNUM， LIS ORRILD
}

British Medical fournal, 1972, 2, 19-21

\section{Summary}

In a population study on the western coast of Greenland the incidence of sucrose malabsorption was estimated by means of sucrose tolerance tests in 190 persons. Smallintestinal disaccharidase activity was estimated in 19 patients. Sucrose malabsorption was present in $10.5 \%$ of the cases studied-a surprisingly high figure and much higher than the incidence reported elsewhere in the world. This incidence is, however, lower than that of lactose malabsorption in Greenland Eskimos (54\%). In contrast to lactose malabsorption, sucrose malabsorption is present from birth; this may have important clinical implications since chronic diarrhoea and malnutrition are fairly common during infancy in Greenland.

\section{Introduction}

Lactase deficiency of the small-intestinal mucosa is not unusual in the adult population of the Western World and, in fact, it seems to be the normal condition in large population groups of the Asian and African continents.

In contrast, sucrose malabsorption, which is always associated with isomaltose malabsorption, occurs sporadically and with much lower frequency than lactose malabsorption. Though occasionally occurring on a hereditary basis sucrose malabsorption has so far not been reported to be confined to or abnormally prevalent in certain ethnic groups.

In Greenland Eskimos lactose malabsorption occurs in more than $50 \%$ of adults and is first noted from about the 6th year of life (Gudmand-Høyer et al., 1972). This figure is based on a population study carried out in three districts of the western coast of Greenland in 1970-1. The primary aim of the study was to establish the incidence of lactose malabsorption and to

\footnotetext{
Medical Department P, Division of Gastroenterology, Rigshospitalet, DK-2100 Copenhagen

A. MCNAIR, CAND. MED.

E. GUDMAND-HEYER, M.D.

S. JARNUM, M.D.

LIS ORRILD, CAND. MED.
}

ascertain its nutritional and clinical significance, if any. In most of the subjects studied, however, the lactose tolerance test was supplemented with a sucrose tolerance test. The results of the latter test form the basis of the present report. They suggest that the incidence of sucrose malabsorption is higher among Greenland Eskimos than among other populations so far studied.

\section{Methods}

The sucrose tolerance tests were carried out with an oral load of sucrose $(50 \mathrm{~g}$ of sucrose dissolved in water for adults, $1.5 \mathrm{~g} / \mathrm{kg}$ for children) given to fasting subjects. Blood sugar determinations by a glucose oxidase method were made on capillary blood before sucrose administration and 15,30, 45, and 60 minutes later. Inquiries were made about diarrhoea and abdominal distress (colic, bloating, borborygmi) during and after the test.

The conditions of the study did not permit a subsequent tolerance test with a mixture of glucose and fructose, the monosaccharide components of sucrose. Instead, the blood sugar rise during a lactose tolerance test was used for comparison or, in the presence of lactose malabsorption, the blood sugar rise during a glucose-galactose tolerance test. A maltose tolerance test was performed in a few cases.

Where possible questions were asked about drinking and eating habits and whether milk or sugar-for instance, sweetswere avoided and for what reasons. Relatives of children were asked about the childrens' growth during infancy and whether they suffered or had suffered from chronic diarrhoea and malnutrition. If so, an attempt was made to establish a time relationship between these symptoms and a change of dietfor instance, supplementation of breast-feeding with sucroseenriched cows' milk.

The enzyme activity of maltase, isomaltase, sucrase, trehalase, and lactase was determined in small-intestinal biopsy samples from the jejunum at or immediately distal to Treitz's ligament. The analyses were performed by A. Dahlquist, Lund, Sweden. The results are reported in detail elsewhere (Asp et al., 1972).

Diagnostic Criteria.-A diagnosis of sucrose malabsorption was accepted if the maximum blood sugar rise during a sucrose tolerance test was less than $25 \mathrm{mg} / 100 \mathrm{ml}$ and the ratio between the maximum rises after sucrose and after glucose-galactose or lactose was less than $\mathbf{0 . 4 0}$. 